\title{
Zagadnienia przystosowania rozwiązań projektowych do potrzeb osób niepełnosprawnych oraz seniorów w nauczaniu projektowania urbanistycznego
}

\author{
Marzena Joanna Siestrzewitowska \\ e-mail:mjb.lublin@onet.eu \\ Katedra Architektury, Urbanistyki I Planowania Przestrzennego, \\ Wydziat Budownictwa i Architektury Politechniki Lubelskiej \\ Department of Architecture, Urban and Spatial Planning, \\ Faculty of Civil Engineering and Architecture of Lublin University of Technology
}

\begin{abstract}
Streszczenie: Artykuł przedstawia założenia programowe przedmiotu Projektowanie urbanistyczne związane z przystosowaniem rozwiązań projektowych dla osób niepełnosprawnych oraz seniorów. Omówiono w nim kolejno: cele przedmiotu, oczekiwane efekty kształcenia, a następnie treści merytoryczne zagadnienia przystosowania przestrzeni otwartych do potrzeb grup o różnych rodzajach niepełnosprawności: osób na wózkach inwalidzkich, głuchych i niedosłyszących, niewidomych, niedowidzących oraz starszych. Dla realizacji tych potrzeb duże znaczenie ma szata informacyjna zespołów urbanistycznych oraz układ socjometryczny jednostki mieszkaniowej, zaprojektowane w sposób wyzwalający w użytkownikach przestrzeni wzajemne uczucia empatii i aprobaty. W dalszej części przedstawiono wymagania formalne, które powinien zawierać każdy projekt wykonywany na przedmiocie z zakresu tej tematyki - tj. rodzaje obowiązkowych przedstawień graficznych wraz z przykładami z semestralnych projektów studenckich.
\end{abstract}

Słowa kluczowe: przystosowanie rozwiązań projektowych, osoby niepełnosprawne, seniorzy, projektowanie urbanistyczne

\section{Cele przedmiotu projektowanie urbanistyczne i oczekiwane efekty kształcenia}

Celem przedmiotu Projektowanie urbanistyczne jest, między innymi, zdobycie przez studentów wiedzy i umiejętności projektowania przestrzeni otwartych przystosowanych dla potrzeb wszystkich użytkowników, niezależnie od stopnia ich niepełnosprawności. Uwrażliwienie studentów na potrzeby osób niepełnosprawnych powinno być jednym z efektów kształcenia w zakresie kompetencji społecznych ${ }^{1}$. Zakłada się też, że na studiach magisterskich studenci, uczący się projektowania osiedli wielorodzinnych, zdobędą wiedzę i umiejętności projektowania urbanistycznego dodatkowej funkcji specyficznej, właściwej dla opracowywanego terenu (np. dworców, zespołów sportowo rekreacyjnych itp.) lub funkcji związanej z aktualnymi wyzwaniami i problemami społecznymi. Dlatego, od dwóch lat studenci zajmują się tematem: „Różne formy zamieszkania dla seniorów zintegrowane z osiedlem wielorodzinnym". Studenci, w czasie wykładów i projektu semestralnego powinni zdobyć wiedzę na temat projektowania takich form zamieszkania w Polsce i na świecie, i umieć zastosować zdobytą wiedzę we własnym projekcie zespołu mieszkaniowego dla seniorów na konkretnym, zadanym terenie.

1 M. J. Siestrzewitowska, Metody prowadzenia zajęć z przedmiotu Projektowanie Urbanistyczne ze studentami kierunku Architektura na Wydziale Budownictwa i Architektury Politechniki Lubelskiej, Teka Komisji Architektury, Urbanistyki i Studiów Krajobrazowych PAN, 2015, nr 4 vol. 11, s. $86-98$, 


\section{Założenia merytoryczne przedmiotu}

Studentów należy uczyć właściwego rozumienia i doceniania wartości przestrzeni publicznych - które powinny być wspólne i ogólnodostępne dla wszystkich, którzy chcą w nich przebywać - oraz wartości społecznej przestrzeni grupowych (sąsiedzkich lub innych - wspólnych dla różnych grup użytkowników). Studenci powinni też rozumieć odpowiedzialność własną za formę i funkcję tych przestrzeni, a tym samym, odpowiedzialność architekta i urbanisty za kształtowanie życia społecznego. Przestrzenie publiczne i grupowe powinny być tak zaprojektowane, aby nie stygmatyzowały i nie wykluczały, ale wyzwalały w użytkownikach tych przestrzeni wzajemne uczucia empatii i aprobaty.

W nauczaniu o konieczności zapewnienia dostępu do obydwu tych rodzajów przestrzeni osobom o różnych stopniach niepełnosprawności i seniorom należy podkreślać znaczenie dobrze zaprojektowanej „szaty informacyjnej wszystkich założeń urbanistycznych" oraz "układu socjometrycznego w jednostce mieszkaniowej”. Autorka zaimplementowała do swoich teorii/rozważań na temat rozwiązywania problemów osób niepełnosprawnych definicje tych pojęć z Teorii urbanistyki w projektowaniu i planowaniu miast Jana Macieja Chmielewskiego ${ }^{2}$.

Układ socjometryczny (zespół wartości komunikacyjnych) powinien tworzyć przyjazną niepełnosprawnym i seniorom "sieć wejść i wyjść, tras pieszych i kołowych, skrzyżowań punktów i przestrzeni dla kontaktów grupowych, przez układ klatek schodowych, galerii i korytarzy, przez liczbę i zasady funkcjonowania wind, przez gęstość i wielkość okien, a zwłaszcza przez wzajemne ich usytuowanie, to znaczy także przez liczbę kondygnacji i kształtów budynków." ${ }^{3}$ Ta sieć komunikacji powinna być bezwzględnie dostępna dla wszystkich niepełnosprawnych, bezpieczna i czytelna. „Ruch pieszy powinien mieć priorytet, bo tylko on zapewnia integrację społeczna.." ${ }^{4}$ Przystosowanie więc projektu urbanistycznego do potrzeb osób niepełnosprawnych polega na dokładnej analizie systemu komunikacji, wyszukaniu wszystkich potencjalnych barier i ich eliminacji poprzez zaproponowanie właściwych udogodnień.

„Na wartości informacyjne środowiska zamieszkania - poza napisami, znakami, plakatami, numerami, nazwami i ogłoszeniami - mają wpływ elementy symboliczne, takie jak: bramy, specjalnie orientowane wyjścia, architektonicznie ukształtowane granice, dominanty urbanistyczne, wreszcie takie wyróżniki, jak: rzeźby, wodotryski, ogródki skalne, charakterystyczne formy roślinności i inne." ${ }^{5}$ Właściwie zaprojektowana szata informacyjna służy wszystkim użytkownikom przestrzeni, ale poprzez wyposażenie jej w elementy dźwiękowe, zapachowe i faktury w posadzkach może bardziej sprzyjać różnym grupom niepełnosprawnych (niewidomym i niedowidzącym). Studenci, projektując więc szatę informacyjną, muszą stosować, poza kryteriami kompozycyjnymi i estetycznymi, kryteria przydatności dla wszystkich użytkowników, wzbogacać ją w treści służące niepełnosprawnym i seniorom, ale też wszystkim innym grupom wiekowym i rodzicom z małymi dziećmi.

Nauczając studentów właściwego projektowania układu socjometrycznego i szaty informacyjnej zespołów urbanistycznych należy podkreślać, że celem projektanta powinno być dążenie do zastosowania takich rozwiązań, aby były one jednocześnie przyjazne dla użytkowników o różnych stopniach sprawności fizycznej i intelektualnej oraz niestygmatyzujące żadnej grupy niepełnosprawnych. Szata informacyjna powinna być w przeważającej części oparta na znakach naturalnych i nieformalnych, które są czytelne dla każdego lub większości uczestników przestrzeni, a więc mających wyraz (funkcję, formę i udogodnienia) akceptujący wszystkich w takim samym stopniu. Tak więc, lepszym rozwiązaniem od urządzenia głośnomówiącego, ustawionego np. na zakręcie/przed bariera, jest pachnący, szeleszczący lub pluskający akcent architektoniczny, szybko zapamiętywalny przez niewidomych (kwietnik, wodotrysk, karmnik dla ptaków, wiatraczek itp.) albo wyraziste kolory akcentów architektonicznych, granic i krawędzi urbanistycznych dla osób niedowidzących, które są jednocześnie atrakcyjnymi elementami przestrzennymi dla wszystkich. Tak samo, zamiast schodów z pochylniami dla wózków inwalidzkich umieszczonymi obok nich, lepszym rozwiązaniem są pochyłe chodniki, które mogą służyć wszystkim.

Należy uczulać studentów, aby udogodnienia dokonywane tylko dla niepełnosprawnych projektować wyłącznie w sytuacjach, gdy rozwiązania uniwersalne nie są możliwe.

2 J.M. Chmielewski, Teoria urbanistyki w projektowaniu i planowaniu miast, Oficyna Wydawnicza Politechniki Warszawskiej, Warszawa, 2005, S. 84-87.

3 A. Wallis, Miasto i przestrzeń, PWN, Warszawa 1978, s. 58, za: J. M. Chmielewski, Teoria...ibid., s. 85

4 M. Wysocki, Dostępna przestrzeń publiczna. Samorząd równych szans, Fundacja Instytut Rozwoju Regionalnego, Kraków 2009, www.firr org.pl/upolads/PUB/Dostepna_przestrzen_publiczna.pdf, stan z 13.10.2016

5 Ibid., s. 59, za: J. M. Chmielewski, Teoria.... op. cit., s. 87 
Jednocześnie należy kłaść nacisk na bezwzględną konieczność eliminacji wszystkich barier dla niepełnosprawnych, których nie można uniknąć i zastąpić ich rozwiązaniami uniwersalnymi ze względu na ukształtowanie powierzchni terenu lub bezpieczeństwo itp. (np. ostrzeżeń dźwiękowych i za pomocą faktury w posadzce przy przejściach przez jezdnię). Należy w takich przypadkach wymagać od studentów zapoznania się z najnowszymi innowacjami technicznymi stosowanymi na świecie.

Zagadnieniem, które powinno być poruszone na zajęciach z projektowania urbanistycznego jest funkcjonowanie w dzisiejszym świecie nie w pełni właściwego podejścia do osób niepełnosprawnych. Obowiązujące przepisy i zasady projektowania w tym zakresie prowadzą zwykle (i jedynie) do likwidowania barier dla niepełnosprawnych, a więc projektowania przestrzeni umożliwiających niepełnosprawnym bezpieczne poruszanie się. Jednak dobrze zaprojektowana przestrzeń publiczna ma nie tylko umożliwiać ludziom przemieszczanie się i załatwianie podstawowych potrzeb. Jej główną funkcją jest stworzenie im warunków do spotkań - wykreowanie miejsca dostarczającego bogatego wachlarza wrażeń (bodźców oddziaływujących na wszystkie zmysły), w którym ci ludzie chcieliby się dłużej zatrzymać. Ważną więc zasadą w nauczaniu projektowania urbanistycznego powinno być podkreślanie tej funkcji przestrzeni publicznych w odniesieniu do wszystkich jej użytkowników - nie tylko tych w pełni sprawnych. Jeśli więc studenci proponują zastosowanie w przestrzeni dominanty kolorystycznej, zaznaczenie kolorem posadzki osi historycznej, nadbrzeży rzeki, ważnej ulicy itp. - powinni również zadbać, aby te same wartości estetyczne/kulturowe/społeczne dotarły do wszystkich w jak największym stopniu poprzez różnego rodzaju bodźce dotykowe, dźwiękowe lub zapachowe, tj. by mogły być odczuwalne przez osoby o różnych rodzajach niepełnosprawności. Przykładowo, projektując miejsca wyjątkowe - np. pomnik, miejsce spotkań dla młodzieży - studenci powinni pomyśleć o zróżnicowaniu kolorystycznym i chropowatości posadzki wokół nich, o elementach wprowadzających dźwięk. M. Wysocki w opracowaniu Dostępna przestrzeń publiczna.. nazywa takie projektowanie "włączającym”, przyjaznym i umożliwiającym udział w życiu społecznym ${ }^{6}$. Głównym przesłaniem nauczania jest więc zaszczepienie w młodym pokoleniu świadomości, że niepełnosprawni mają - poza problemami podstawowymi - również inne ważne potrzeby wyższe (obcowania ze sztuką, głębokiej percepcji przestrzeni/natury/świata, poczucia tożsamości, świadomości historycznej i społecznej) takie same jak osoby w pełni sprawne.

Proponując studentom temat zabudowy mieszkaniowej dla seniorów, należy zwrócić uwagę na konieczność projektowania różnorodnych jej form, w zależności od statusu materialnego przyszłych użytkowników. Należy podkreślać zmiany kulturowe w podchodzeniu do opieki nad seniorami, zwłaszcza potrzeby i oczekiwania samych seniorów, którzy coraz częściej wykluczają możliwość spędzenia ostatnich lat życia w wyłącznej zależności od rodziny. Tak więc, oferta dla seniorów może zawierać propozycję mieszkania w zespołach domów jednorodzinnych różnych typów (wolno stojących, bliźniaczych, szeregowych) wyposażonych w kompleks specjalistycznych usług medycznych i bytowych dla osób starszych wraz z całodobową opieką pielęgniarską (dla najlepiej sytuowanych) lub propozycję zamieszkania w małych willach z kilkoma niewielkimi mieszkaniami na każdym piętrze dla samotnych lub małżeństw, również z kompleksem usług. Rekomenduje się również, przy projektowaniu zabudowy wielorodzinnej, planowanie małych mieszkań dla seniorów z usługami zgrupowanymi na jednej kondygnacji, zwłaszcza parterze, lub w łącznikach pomiędzy blokami, zapewniającymi możliwość wspólnego żywienia, opiekę lekarską i pielęgniarską oraz rozrywkę i możliwość kontaktów towarzyskich - dla osób z mniejszymi dochodami.

Bardzo ważnym czynnikiem uwrażliwienia studentów na potrzeby osób starszych powinno być zadanie zaprojektowania otwartej przestrzeni sąsiedzkiej dla seniorów, zarówno wśród domów jednorodzinnych, jak i pomiędzy blokami wielorodzinnymi. Należy zwrócić uwagę studentów na to, aby mała architektura projektowana w tej przestrzeni była przystosowana do ich potrzeb, możliwości i wymagań.

Istotne powinno być zwrócenie uwagi studentów na modne, i nagminne obecnie, projektowanie przestrzeni publicznej nieprzychylnej seniorom, zwłaszcza, tak samo nieprzychylnym im, miejsc do siedzenia w obiektach kultury, użyteczności publicznej, na tarasach widokowych itp. Projektowane obecnie, i nagradzane, miejsca wypoczynku w przestrzeni publicznej mają, przede wszystkim, walor artystyczny (rzeźb w przestrzeni), natomiast nie są zgodne z nauką ergonomii, zwłaszcza nie mają odniesienia do specyficznych wymagań formy fizycznej i wymiarów sylwetki osób starszych. Za poważny błąd i pretensjonalną manierę należy uznać projektowanie miejsc do siedzenia pozbawionych oparcia (nie mówiąc już o ich właściwym wyprofilowaniu) i zabronić 
stosowania takich form nie tylko w przestrzeniach sąsiedzkich dla seniorów, ale również w przestrzeni publicznej całego osiedla/miasta.

Powinno się wykluczyć możliwość „zamknięcia” przez studencki zespół projektowy tematu zabudowy dla seniorów w propozycji budowy na osiedlu wielorodzinnym tradycyjnego domu seniora. Jest to temat właściwy do przemyślenia w skali architektonicznej, natomiast w skali urbanistycznej nie prowadzi do uwrażliwienia na potrzeby osób starszych, kończąc wszystkie potencjalne rozważania rysunkiem jednej bryły.

\section{Założenia formalne przedmiotu}

1) Do każdego projektu urbanistycznego, po zakończeniu fazy opracowania koncepcji zagospodarowania przestrzennego terenu, studenci są zobowiązani wykonać schemat rozwiązań projektowych dla potrzeb osób niepełnosprawnych - niewidomych i niesłyszących oraz na wózkach inwalidzkich, które powinny być zrealizowane w przestrzeniach otwartych (nie nanoszą rozwiązań w budynkach - w których, zgodnie z przepisami, powinny być zlikwidowane bariery architektoniczne). Na schemacie studenci mają za zadnie wskazać miejsca, w których istnieją bariery lub niebezpieczeństwa dla niepełnosprawnych wymagające zastosowania specjalnych rozwiązań (ponumerować, oznaczyć literami lub piktogramami) i objaśnić w legendzie (Ryc. 1.), lub pokazać na odnośnikach (Ryc. 3.).

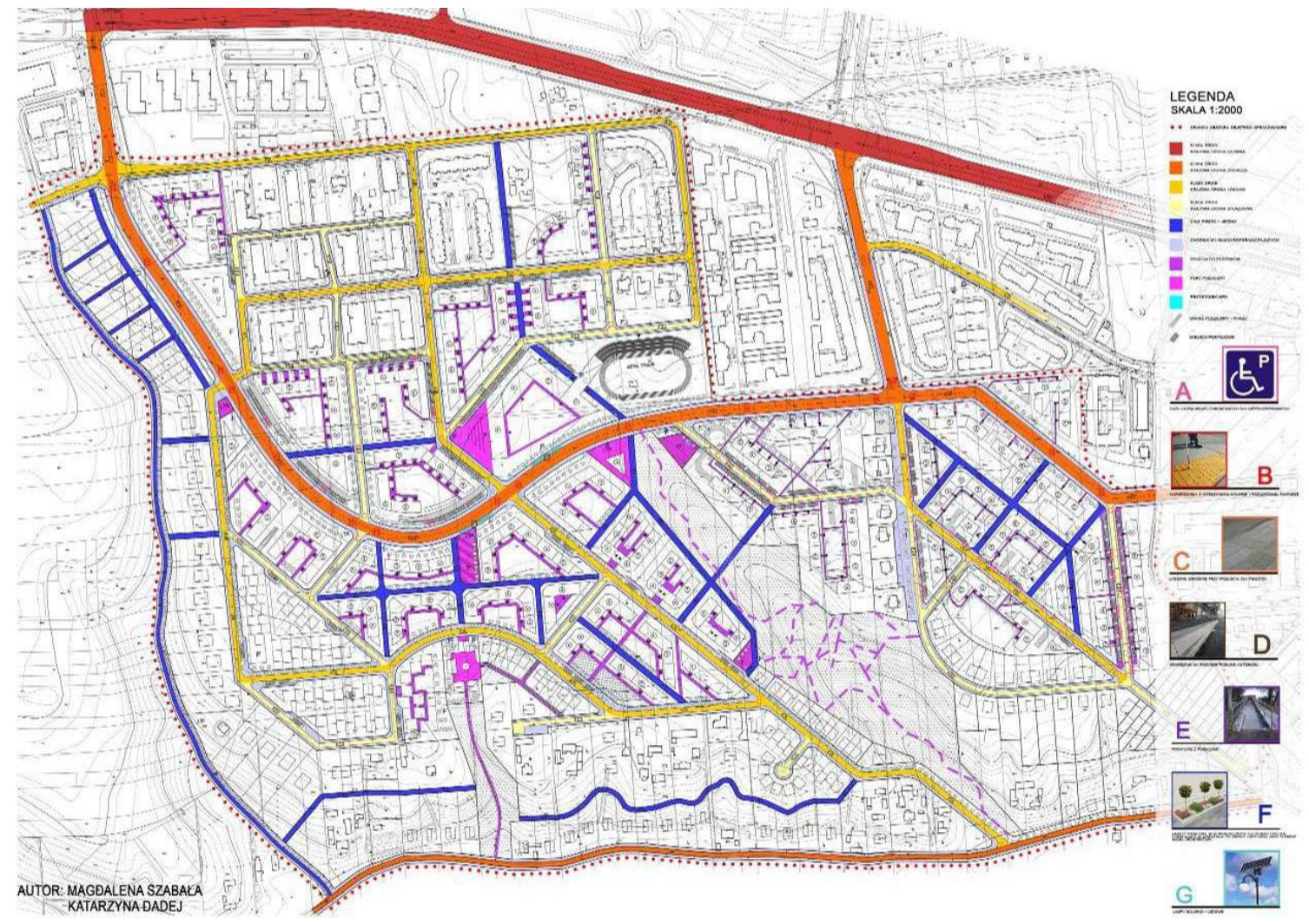

Ryc. 1. Schemat przystosowania rozwiązań projektowych do potrzeb osób niepełnosprawnych oraz schemat komunikacji. Projekt studencki osiedla wielorodzinnego w dzielnicy Węglin-Południe w Lublinie, proj. Magdalena Szabała, Katarzyna Dadej

A schema of adapting design solutions to the needs of people with disabilities and a schema of a communication system. A students' project of a housing estate in district Węglin-Południe of Lublin, proj. Magdalena Szabała, Katarzyna Dadej

Pokazują rozwiązania techniczne (np. „położone płasko” krawężniki przy przejściach dla pieszych oraz rampy przy schodach terenowych - dla osób na wózkach inwalidzkich, świetlne linie prowadzące w posadzkach placów i promenad - dla niedowidzących, miejsca lokalizacji makiety pokazującej zagospodarowanie przestrzeni 
publicznej oraz miejsca lokalizacji sygnalizacji i informacji dźwiękowej - dla niewidomych itp. oraz inne rozwiązania oddziaływujące na wszystkie zmysły i ułatwiające niepełnosprawnym percepcję otaczającego świata (Ryc. 2.).

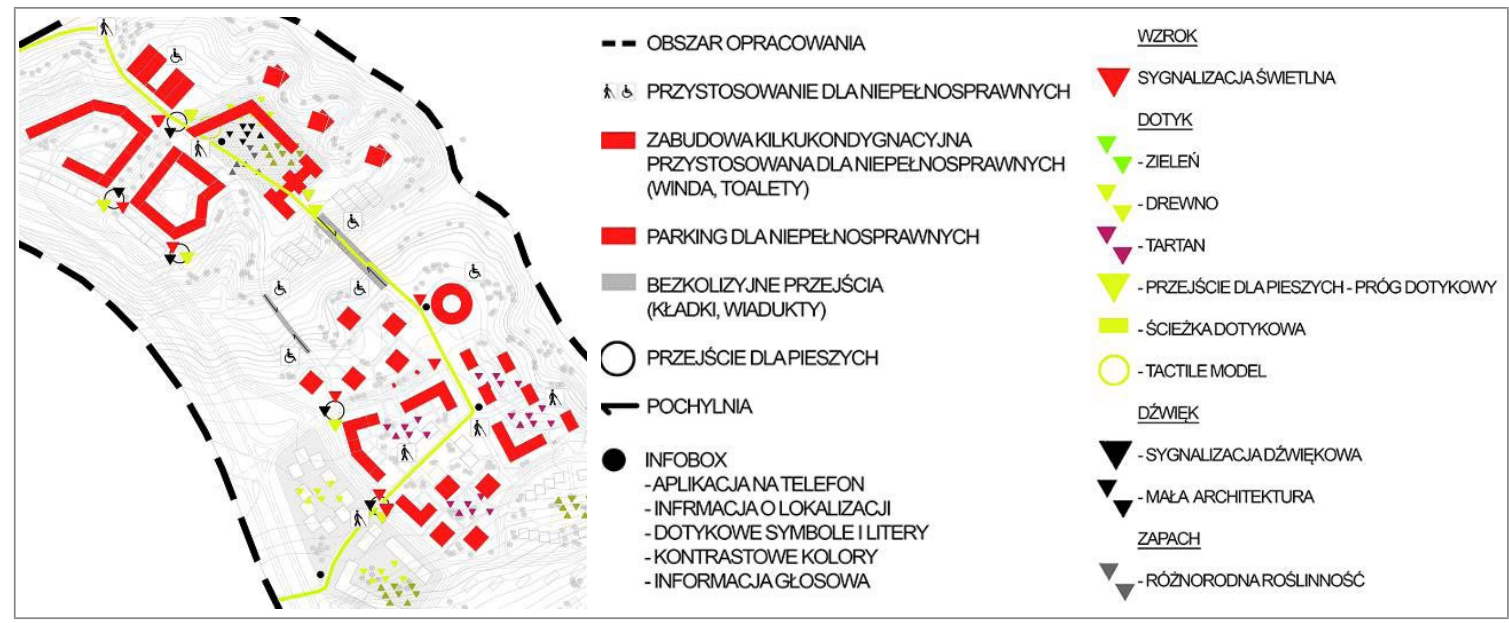

Ryc. 2. Schemat przystosowania rozwiązań projektowych do potrzeb osób niepełnosprawnych. Projekt studencki osiedla wielorodzinnego w Jakubowicach Murowanych w Lublinie, proj. M. Bednarczyk, Ł. Buczek, J. Korona, M. Radkiewicz, M. Semeniuk A schema of adapting design solutions to the needs of people with disabilities. A students' project of a housing estate Jakubowice Murowane in Lublin, proj. M. Bednarczyk, Ł. Buczek, J. Korona, M. Radkiewicz, M. Semeniuk
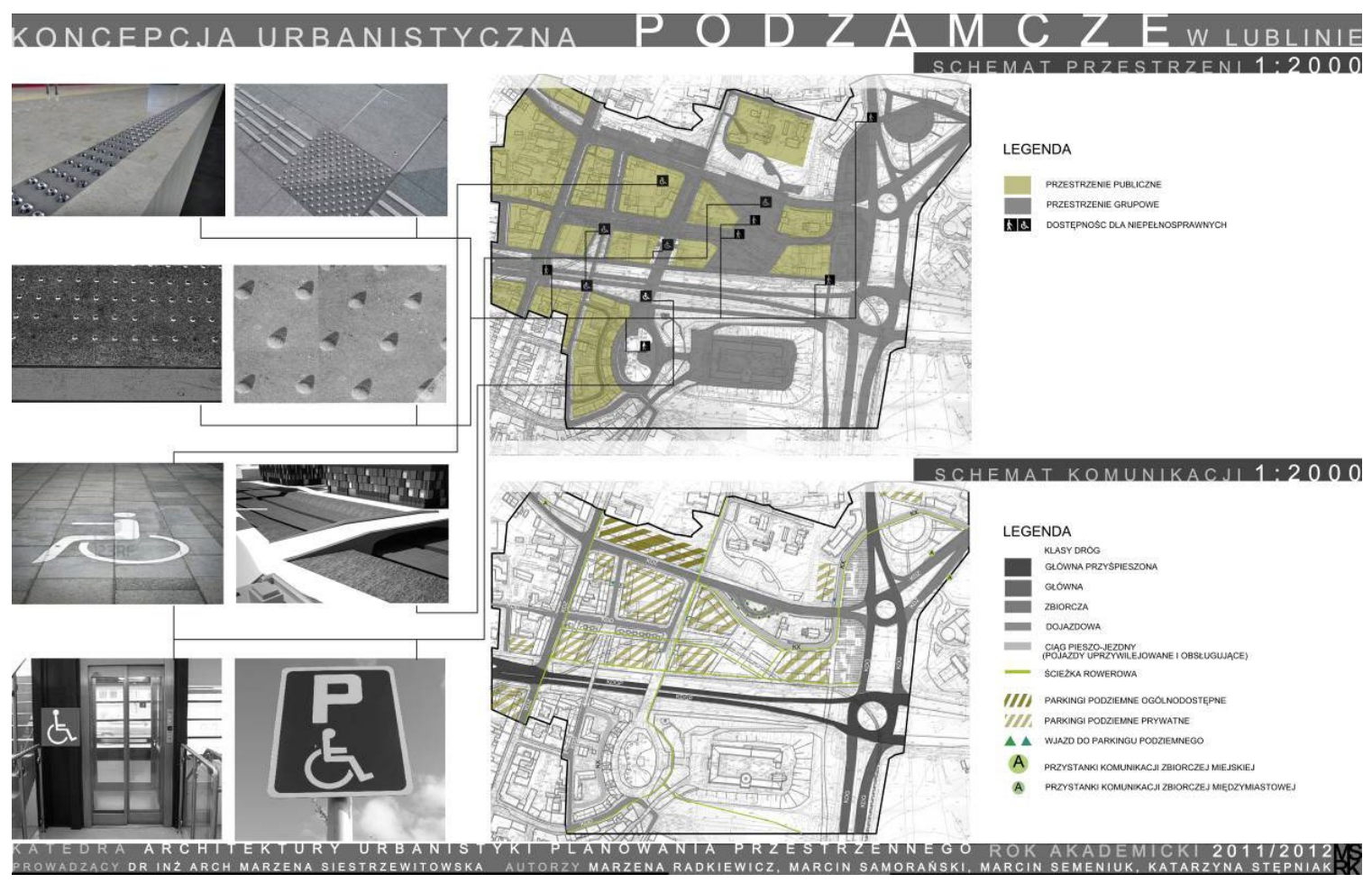

Ryc. 3. Schemat przystosowania rozwiązań projektowych do potrzeb osób niepełnosprawnych oraz schemat komunikacji. Projekt studencki „Koncepcja zagospodarowania przestrzennego Podzamcza w Lublinie”, proj. M. Radkiewicz, M. Samorański, M. Semeniuk, K. Stępniak

A schema of adapting design solutions to the needs of people with disabilities and a schema of a communication system. A students' project "A plan of the Podzamcze spatial development in Lublin", proj. M. Radkiewicz, M. Samorański, M. Semeniuk, K. Stępniak 


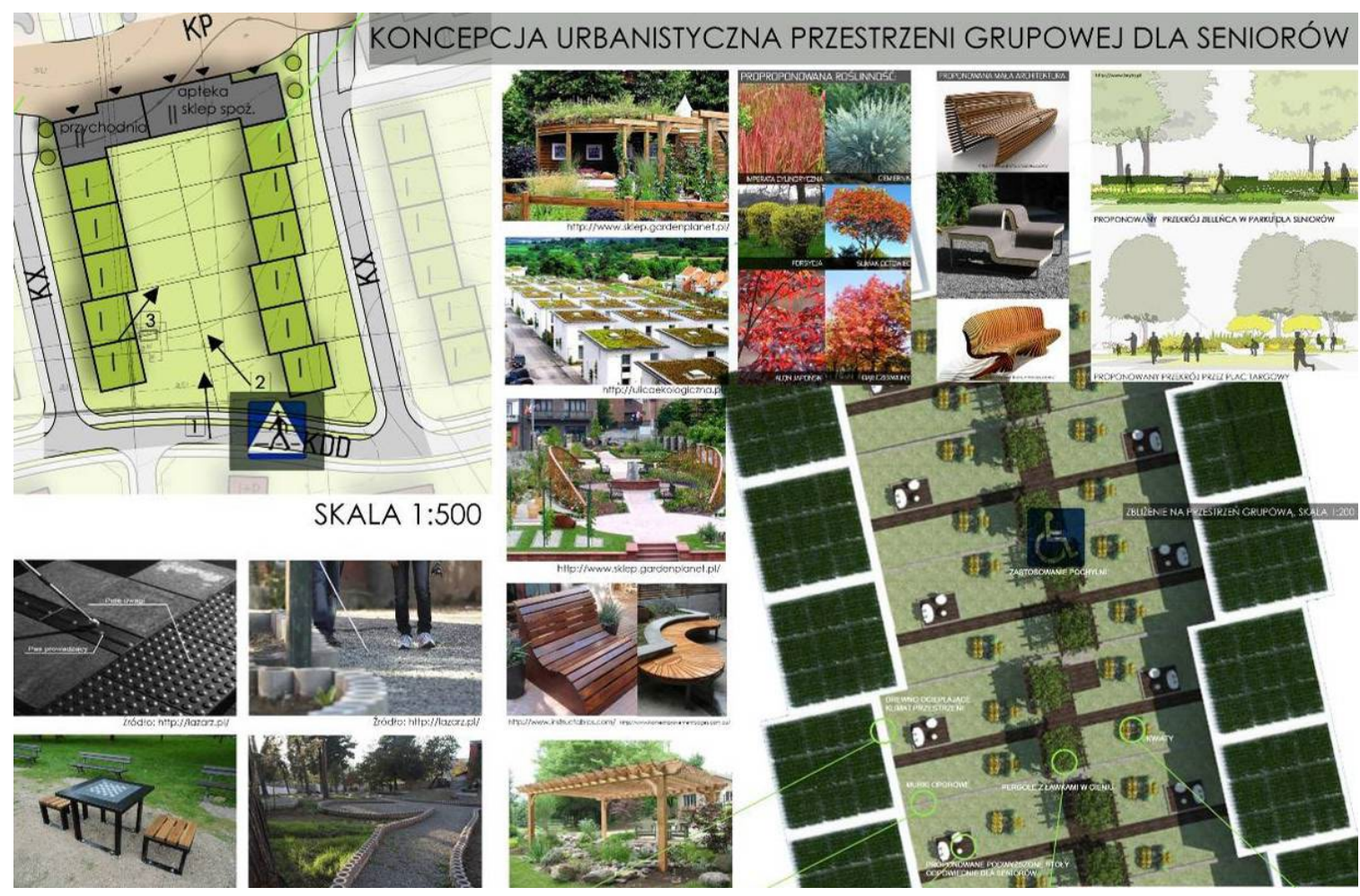

Ryc. 4. Projekt studencki "Różne formy zamieszkania dla seniorów zintegrowane z osiedlem wielorodzinnym” w dzielnicy Węglin-Południe w Lublinie, proj. B. Borzęcki, A. Duda, N. Dyduk, W. Frączysta

A student's project: "Various forms of residential for seniors integrated with housing estate apartment buildings" in district Węglin-Południe of Lublin, proj. B. Borzęcki, A. Duda, N. Dyduk, W. Frączysta

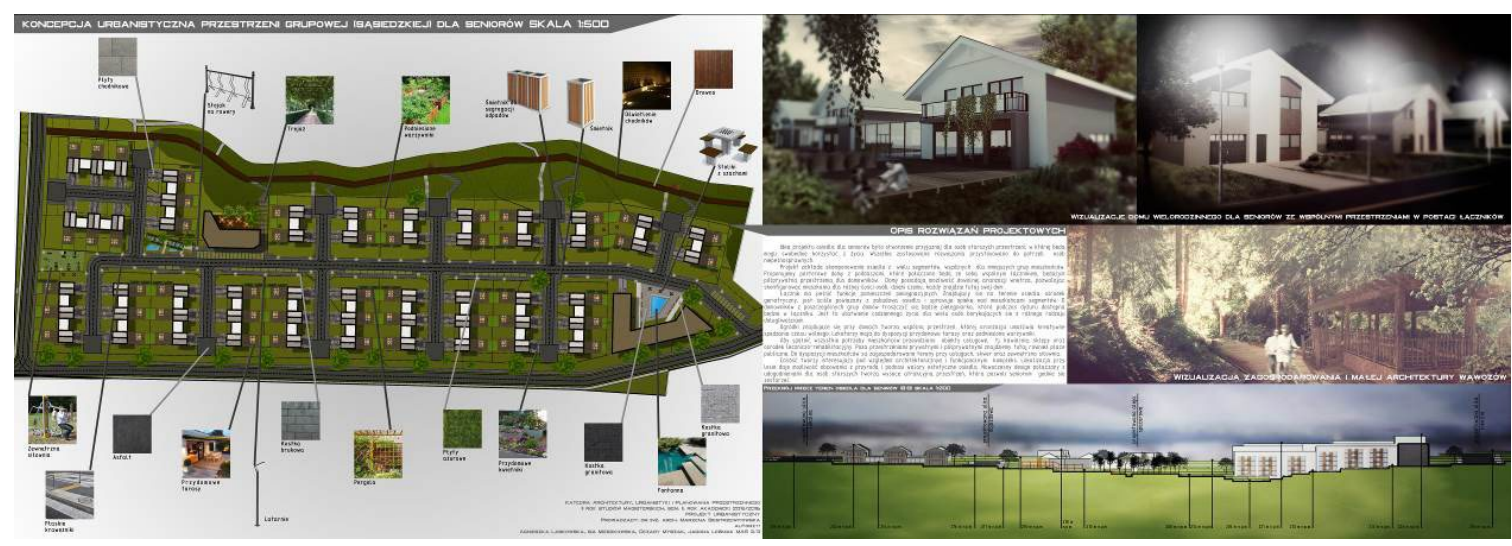

Ryc. 5. Projekt studencki „Różne formy zamieszkania dla seniorów zintegrowane z osiedlem wielorodzinnym” w dzielnicy Węglin-Południe w Lublinie, proj. A. Laskowska, I. Mieszkowska, C. Myszak, J. Leśniak

A student's project: „Various forms of residential for seniors integrated with housing estate apartment buildings" in district Węglin-Południe of Lublin, proj. A. Laskowska, I. Mieszkowska, C. Myszak, J. Leśniak

Obok schematu studenci mogą zamieścić zdjęcia takich przykładowych rozwiązań, np. z literatury lub Internetu (Ryc. 1, Ryc. 3) - grafika i sposób opisania miejsc udogodnień są dowolne. Mogą również dołączyć do tej części projektu detale techniczne zagospodarowania terenu dotyczące rozwiązań służących niepełnosprawnym w pokonywaniu różnych barier lub służące im projekty małej architektury oraz obrazujące je szkice, 
schematy i fotografie. Można też zachęcić studentów do pokazania drogi poruszania się niepełnosprawnych w podstawowych kierunkach na przekrojach urbanistycznych w skali 1:500 (z podaniem wyliczenia procentowego pochylenia ciągów pieszych na kontrowersyjnych odcinkach drogi - zgodnego z przepisami), żeby sprawdzić, czy projekt zapewnia możliwość dostania się niepełnosprawnego do najważniejszych miejsc w rejonie swojego zamieszkania.

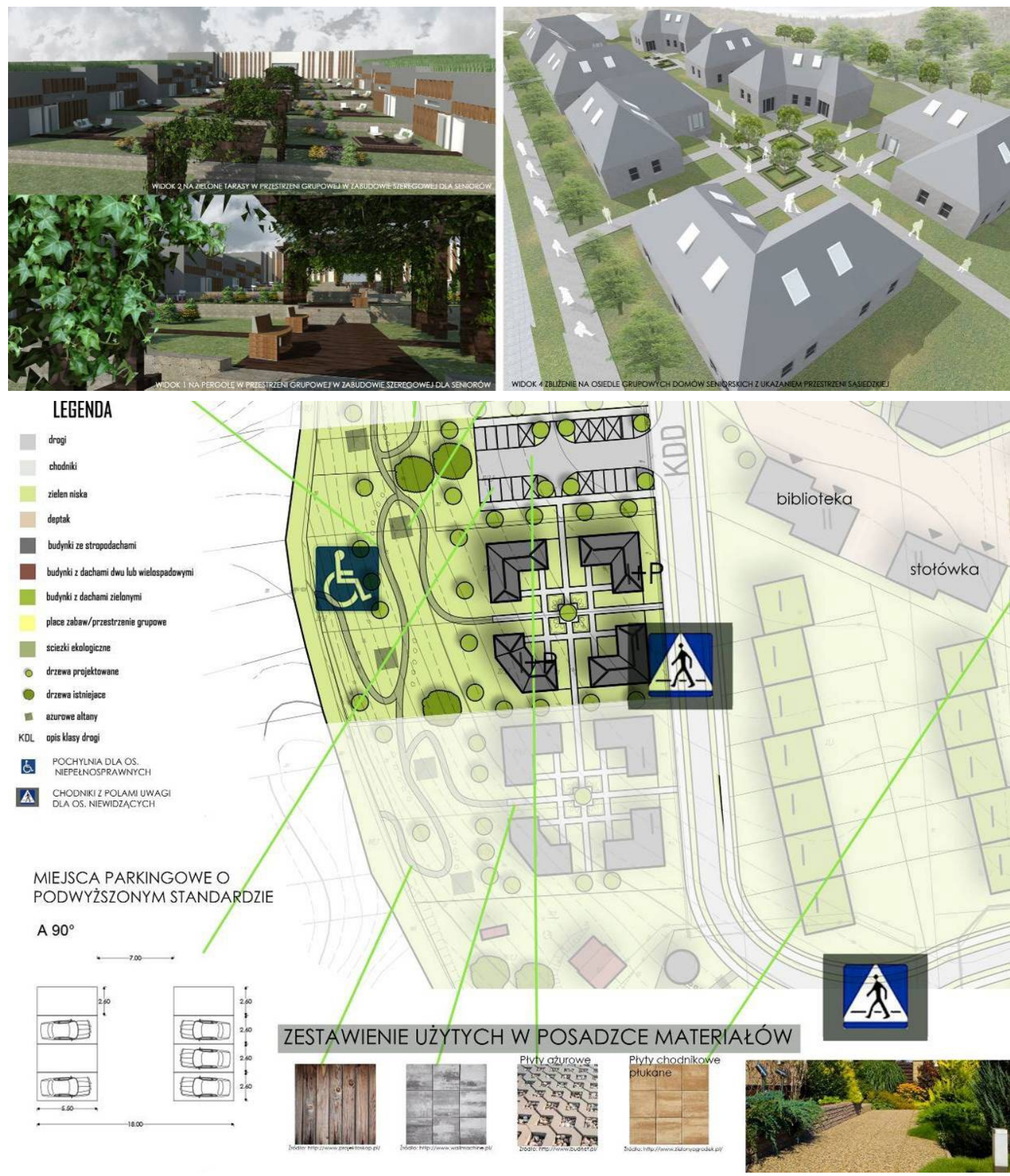

Ryc. 6. Projekt studencki „Różne formy zamieszkania dla seniorów zintegrowane z osiedlem wielorodzinnym” w dzielnicy Węglin-Południe w Lublinie, proj. proj. B. Borzęcki, A. Duda, N. Dyduk, W. Frączysta

A students' project: „Various forms of residential for seniors integrated with housing estate apartment buildings in district Węglin-Południe of Lublin, proj. proj. B. Borzęcki, A. Duda, N. Dyduk, W. Frączysta 
2) W prowadzonym obecnie projekcie „Różne formy zamieszkania dla seniorów zintegrowane z osiedlem wielorodzinnym" studenci mają za zadanie, po zakończeniu analiz urbanistycznych terenu, napisać pracę (esej, artykuł) na temat sposobów rozwiązywania problemów zamieszkiwania osób starszych i opieki nad nimi stosowanych w Polsce i na świecie. Po takim przygotowaniu, studenci dostają zadanie wpisania w projektowane osiedle wielorodzinne jednego lub kilku zespołów zabudowy dla seniorów (pokazania ich układu urbanistycznego na koncepcji zagospodarowania przestrzennego opracowywanego terenu zabudowy mieszkaniowej w skali 1:1000 oraz wyjaśnienia zasady jego funkcjonowania na schematach obrazujących układ funkcji i komunikacji).

W ostatniej fazie projektu studenci zajmują się rozwiązywaniem przestrzeni sąsiedzkiej w zespole dla seniorów na rzucie w skali 1:500 oraz pokazują zalety tego zespołu, jego klimat architektoniczny i małą architekturę poprzez prezentację przekrojów urbanistycznych, wizualizacji z poziomu człowieka oraz detali technicznych (Ryc. 4, 5, 6,).

\section{Podsumowanie}

Innowacje w urbanistyce, zwłaszcza w projektowaniu przestrzeni publicznych, powinny prowadzić do osiągania uniwersalności wszelkich rozwiązań, tj. uwzględniać potrzeby wszystkich użytkowników przestrzeni na równoprawnych zasadach, bez względu na niepełnosprawność. Przystosowanie przestrzeni otwartych dla potrzeb osób niepełnosprawnych nie może być ograniczone do likwidacji barier komunikacyjnych i zapewnieniu fizycznego dostępu do wszystkich miejsc. Powinno polegać też na rozwiązaniach projektowych wykorzystujących i uruchomiających wszystkie zmysły, umożliwiać każdemu niepełnosprawnemu realizację potrzeb wyższych związanych z dostępem do kultury oraz jak najgłębszą percepcję otaczającego go świata.

Oczekiwanie od uczelni technicznej wyłącznie efektów kształcenia w zakresie wiedzy i umiejętności dotyczących rozwiązań technicznych jest niewystarczające. Należy zwrócić baczniejszą uwagę na efekty w zakresie kompetencji społecznych i nie traktować ich jako skutków ubocznych nauczania, osiąganych "przy okazji”. Zagadnienia przystosowania rozwiązań projektowych do potrzeb osób niepełnosprawnych oraz seniorów analizowane na różnych przedmiotach na wydziałach budownictwa i architektury powinny być przyczynkiem do kształtowania postaw obywatelskich/prospołecznych ale też do rozwijania u studentów otwartości na drugiego człowieka, tolerancji i empatii. Należy więc, nie tylko żądać od studentów poprawnych pod względem technicznym projektów i odwoływać się do obowiązujących przepisów prawa, ale też w nauczaniu o omawianym zagadnieniu nawiązywać do etyki zawodowej oraz moralnych zasad współżycia społecznego.

\section{Literatura}

[1] Chmielewski J.M., Teoria urbanistyki w projektowaniu i planowaniu miast, Oficyna Wydawnicza Politechniki Warszawskiej, Warszawa, 2005, s. 84-87,

[2] Siestrzewitowska M. J., Metody prowadzenia zajęć z przedmiotu Projektowanie Urbanistyczne ze studentami kierunku Architektura na Wydziale Budownictwa i Architektury Politechniki Lubelskiej, Teka Komisji Architektury, Urbanistyki i Studiów Krajobrazowych PAN, 2015, nr 4, vol. 11, s. 86-98,

[3] Wallis A., Miasto i przestrzeń, PWN, Warszawa 1978, s. 58, za: J. M. Chmielewski, Teoria urbanistyki w projektowaniu i planowaniu miast, Oficyna Wydawnicza Politechniki Warszawskiej, Warszawa, 2005, s. 85

[4] Wysocki M., Dostępna przestrzeń publiczna. Samorząd równych szans, Fundacja Instytut Rozwoju Regionalnego, Kraków 2009, www.firr.org.pl/upolads/PUB/Dostepna_przestrzen_publiczna.pdf, stan z 13.10.2016. 


\title{
Issues of adapting design solutions to the needs of seniors and people with disabilities in teaching urban design
}

\begin{abstract}
The paper presents the principles of Urban Design related to adapting design solutions for seniors and people with disabilities. After introducing the objectives of the topic as well as the expected results of teaching, it discusses substantive content of the issue of adapting open spaces to the needs of groups with various disabilities: wheelchair users, the deaf, people with hearing-impairement, the blind, visually impaired and the elderly. For the execution of those needs, informational outcome on urban array and sociometric pattern of individual housing unit, planned to instill reciprocal feelings of empathy and approval, are of utmost importance. The further part of the paper presents formal requirements, which should be taken into consideration in every project related to the scope of the subject matter - i.e., types of mandatory graphical representations along with examples of semester projects of the students.
\end{abstract}

Keywords: adaptation of design solutions, people with disabilities, seniors, urban design 